\title{
Management of Operating Room Critical Events
}

Editor ALEXANDER A. HANNENBERG

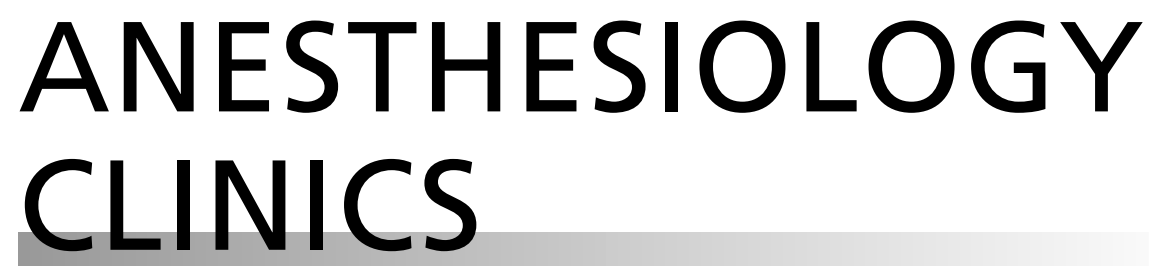

www.anesthesiology.theclinics.com

Consulting Editor

LEE A. FLEISHER

December $2020 \bullet$ Volume $38 \bullet$ Number 4 